\title{
BENJAMIN CONSTANT AND THE DOCTRINAIRE LIBERAL INFLUENCE IN HISPANIC AMERICA
}

\author{
By O. Carlos Stoetzer
}

In colonial times Hispanic American thought had always been influenced by the Peninsula, but gradually other parts of Europe began to play an increasing role in the development of the Hispanic American mind, especially France. In the first half of the nineteenth century Europe found itself in the Romantic age, and Hispanic America came under the strong spell of Romanticism, although the old Scholastic theories and the currents of the Enlightenment were by no means exhausted. Three major currents of thought played a significant role in France after the fall of Napoleon. On one side there was the movement of "Idéologie" which continued the main currents of the eighteenth century and the postulates of the French Revolution ${ }^{1}$. On the other side there was the movement of the Traditionalists who wished to restore both papal and royal power and who believed that freedom of conscience could only be attained through a strong Catholic renewal and true political liberty only through traditional monarchy ${ }^{2}$. A third group which tried to establish a middle way, a kind of via media, were the fascinating Doctrinaire Liberals. Realizing that it was impossible to ignore the revolutionary events of 1789 this group attempted to apply the Hegelian synthesis to the new age. They were a conservative lot but held rather moderate political views. Between the extremes of popular sovereignty and monarchical absolutism they came up with the sovereignty of reason ${ }^{3}$. The early members of this group came from the idéologues, such as Laromiguière and Dégérando ${ }^{4}$, but their main representatives were Victor Cousin and Maine de Biram in philosophy, and Pierre Paul Royer-Collard in the field of politics. Besides these men, the Doctrinaires included such important figures as Prosper de Barante, Serre, François Guizot, the Duke de Broglie, Charles Rémusat, Beugnot, Molé, Mounier, Sebastiani, Camille Jordan, and the Count de Saint Aulaire in France; Alcalá Galiano, Martínez de la Rosa, Juan Donoso Cortés in his early life, and Antonio Cánovas del Castillo in Spain. Though not entirely a part of the Doctrinaire Liberal movement but closely related to it were also Alexis de Tocqueville and Benjamin Constant de Rebecque. Both the Doctrinaire Liberals and Constant developed an aristocratic and elitist thought by no means reactionary, a progressive though not radical, ideology which would not only be an interesting intellectual novelty but also a workable and efficient political program. Realizing that the rising forces of industrialization and capitalism, the middle classes, needed a political system which gave the bourgeoisie both security and power, they opted for constitutional monarchy, since the Revolution had gone too far with anarchy and terrorism, and the Napoleonic system had proved as arbitrary as the Enlightened Despotism of the eighteenth century. Just as the Restoration was a compromise between reaction

\footnotetext{
* Prepared for delivery to the Duquesne History Forum, Duquesne University, Pittsburgh, Pennsylvania October 20, 1977.

1 G. de Bertier de Sauvigny, La Restauration (Paris, 1955), p. 468.

2 Juan Beneyto Pérez, Historia de las doctrinas políticas (Madrid, 1958), p. 375.

3 Ibid., p. 376.

4 Luis Díez del Corral, El liberalismo doctrinario (Madrid, 1956), pp. 29-30.
} 
and revolution, the Doctrinaire Liberal formula was thus a compromise between the monarchical principle and national sovereignty, where the constitution, as a modern, rational and written version of the old medieval God-oriented monarchy, imbedded in Scholastic natural law, was now handed down by the crown - the constitution octroyée as exemplified by the Charter of 1814 - and was not forced by the people on the prince, as in the case of the French Constitution of 1791.

The philosophie foundation for the Doctrinaire Liberal movement had been furnished by Victor Cousin (1792-1867) who became the founder of the School of Ecclecticism. Influenced by German philosophy (Idealism and Historicism), fighting sensualism and materialism, Cousin also absorbed much of the philosophy of the Scottish Schools, and was a disciple of Herder. In 1815 Cousin replaced Royer-Collard in the chair of philosophy and succeeded in giving to this third force an outstanding influence, especially a popularization which went beyond the actual value of the entire movement. Cousin stated that the eighteenth century had been a century of destruction, and that the nineteenth century ought to be an intelligent rehabilitation. He recommended a philosophical system of an enlightened ecclecticism which would judge all schools of thought with equity and objectivity and would take only what was true and eliminate what was false. The new philosophy would defend the healthy, noble, generous ideas, which did not go against religion and the prevailing social order, and thus could base itself on the eternal values of what was "true, beautiful and good"6. Cousin's ecclectic spiritualism projected its political implications to the Doctrinaire Liberal movement. Purged of certain excesses Cousin's Ecclecticism facilitated the conciliation of the extremes and created an atmosphere in which a settlement along the lines of the via media became a tangible possibility?

The Doctrinaires merited their name because it was their doctrine to have none and they represented a political point of view which left a large leeway for compromise and adjustment to reality and circumstances. All were influenced by England and Germany: Royer-Collard had introduced the Scottish School in France; Serre, Jordan and Broglie had lived in Germany; Guizot and Barante in Geneva $^{8}$; Constant as a Swiss had lived and studied in Germany (Erlangen, Brunswick) and Britain (Edinburgh, Oxford, London).

The new pattern created by the Doctrinaires became in due course the typical form of government in the nineteenth and partly twentieth centuries, the continental Rechtsstaat of Robert von Mohl9, although in time the democratic tendencies increased and the original aristocratic-upper bourgeoisie character decreased. This Doctrinaire philosophy was rooted in several intellectual sources: Kant's influence (through the Scottish School) represented an important part of their thought, but the Kant which Cousin introduced into France was different from the original in that Cousin mistook Kant for a sceptic. Also, instead of Kant's reason, Cousin

\footnotetext{
5 The Scottish School of Thought (Hamilton, Reid) combatted French materialism (Holbach, Helvetius, Condillac) and Hume's sensualist empirism in the name of common sense; later it based itself also somewhat on Kant.

6 Bertier de Sauvigny, p. 473. Though Cousin's work Du Vrai, Du Beau et Du Bien appeared in 1854 it reproduced simply what he had taught during the Restoration.

7 Díez del Corral, p. 41.

8 Ibid., p. 142.

9 Cf. Robert von Mohl, Die deutsche Polizeiwissenschaft und die Grundsätze des Rechtsstaates (3 vols.; Tübingen, 1832-1834).
} 
veered into the direction of Hegel adopting the Hegelian absolute reason in order to overcome eighteenth-century rationalism. The Hegelian system offered a rationalistic construction with an historical and social meaning plus a subjective and objective dialectic which is important for an understanding of Guizot's representative government on the basis of reason ${ }^{10}$. However, the Hegel Guizot assimilated was as different as the Kant Cousin appropriated, and if this metamorphosis occurred already in France, how distorted will be the picture of the Rechtsstaat, of the Liberal state, once it reached the Hispanic American shores! In contrast to Hegel Guizot believed in a personal, Christian God ${ }^{11}$, and it was this Christian background which made the Ecclecticism of Cousin and the political theory of Royer-Collard and his movement so fascinating to Hispanic America, always eager to follow an ideal with a Christian basis. Thus, Doctrinaire constitutional government based on the concept of reason arrived at a representation not from below as the eighteenth-century rationalistic thought and Rousseau, but from above as exemplified in the Charter of 1814 which was handed down by the monarch and was not settled through a social contract: this became the most important foundation of the Doctrinaire movement, including that of Constant.

One of the most original and interesting ideas of the Doctrinaire Liberals was the concept of the fourth power, the theory of the moderating power, le pouvoir neutre. 'The legal basis was put forward by Chateaubriand in his "La monarchie selon la charte", since the king was inviolable and the ministers responsible. However, the theory came from Stanislas de Clermont-Tonnerre who had mentioned two executive powers: the royal and the ministerial, and it was Constant who had expanded it in his "Réflexions sur les constitutions, la distribution des pouvoirs et les garanties dans une monarchie constitutionelle" (Paris, 1814) giving it a deep doctrinal basis" ${ }^{12}$. In the later "Principes de politique applicables à tous les Gouvernements représentatifs et particulièrement à la constitution actuelle de la France" (Paris, 1815), he criticized earlier constitutions with the following statement: "The vice of almost all constitutions has been not to have established a neutral power, but to have placed the sum total of authority with which it must be invested in one of the active powers" ${ }^{13}$, and on another occasion he said that sovereignty was neither vested in the king nor in a fictitious concept of the nation but in the Nation as represented by the constituted elements of the various powers at whose head was the king ${ }^{14}$.

Constitutional monarchy offered the best possible application of this novel theory in the person of the neutralized king and actually led to the neutralization of monarchy, without however considering monarchy as obsolete or superfluous. On the contrary, royal power in this political theory had a very delicate and highly significant role to play, which later, in 1819, was called by Count Lanjuinais "une autorité modératrice, médiatrice, directoriale"15. This moderating power represented a conservative force which would bring cohesion to the other three powers and as such seemed to be a better abstraction of the British unwritten

10 Díez del Corral, pp. 197-98.

11 Ibid., p. 199.

12 Ibid., pp. $95-96$.

13 Lothar Gall, Benjamin Constant. Seine politische Ideenwelt und der deutsche Vormärz (Wiesbaden, 1963),

14 ibid., p. 175.

15 Ibid., p. 174. 
constitution than Montesquieu and Delolme had done a century earlier. Constant had taken the last consequence of the successive neutralization of royal power which characterized the modern era ${ }^{16}$, but while the neutralization of monarchy in England had practically been achieved, in France this was done formally ${ }^{17}$. Constant argued that monarchy thus ridden of dangerous elements was the most important power not only for the good functioning of government but more so in assuring a stable political element protected on one side by legitimacy and on the other by its governing insignificance. But here was a difference between Constant and the Doctrinaires. Legitimacy für Constant did not mean a superior foundation of a moral, legal or historical nature, as the Doctrinaire Liberals believed, but simply and exclusively a mechanism to sustain the abstract construction, a utilitarian instrument. Hence, the consequences were also clear: Constant saw no difference in the Bourbons, the Bonapartists, or the Orléanistes as long as his fourth power fulfilled the role of the Rechtsstaat in the fashion which was to be realized with Louis Philippe: "Le roi règne, mais ne gouverne pas." For the Doctrinaires on the other hand, this fourth power had a different meaning: thus Royer-Collard saw in it not only the moderator within the three classical powers of Montesquieu but extended it to the entire national life and in an historical range, as an image of Providence: a prince above all passions ${ }^{18}$.

Until the time the young Constant fell under the spell of Germaine de Staël about the age of 26 years (1794) - he was a man of the Age of Reason, and it was under her influence that a deep metamorphosis took place which led to a new philosophical approach in line with the Romantic Age ${ }^{19}$. John Locke remained, however, Constant's constitutional idol. All his life he preached "reform instead of revolution", admired British institutions and believed that a constitutional monarchy would better serve the interests of liberty than a republic ${ }^{20}$, opinions which later were shared in regard to Imperial Brazil by such men as President Rojas Paúl of Venezuela and Joaquim Nabuco. Like the Doctrinaire Liberals, Constant had no use for democracy, and in view of the democratic excesses through which the revolution of 1789 had gone he loathed the democratic system with the same implacable hatred as the Doctrinaires of Royer-Collard and Guizot $^{21}$. It was for these reasons that as far as suffrage was concerned Constant wanted political rights to be restricted to those with landed property, since this political requirement provided the necessary security and stability ${ }^{22}$.

Another guarantee against despotism was for Constant provincial and municipal autonomy, and finally, Constant considered political parties like religious sects. In his view their success would depend on their greater authority and morality. Thus there arose a distinciton which was to lead to two different systems: the parliamentary and the strictly constitutional23. It was Constant who had remarked with great perspicacity that "variety is life; uniformity death" 24 . He was also, as J. L. Talmon stated, "perhaps the first thinker to realize that the despotism of the

16 Díez del Corral, p. 99.

17 Ibid., pp. 100-103.

18 Ibid., pp. 104 and 107.

19 Gall, p. 5.

20 Ibid., pp. 39 , ix and $x$.

21 Guido de Ruggiero, Historia del liberalismo europeo (Span. trans.; Madrid, 1944), p. 103.

22 Ibid., p. 90.

22 Ibid., p. $90.99,95-96,97$.

24 Juan Vallet de Goytisolo, "El mito de la igualdad", Roma (Buenos Aires, Argentina), VI, 27 (summer 1972-1973), p. 41. 
divine right of kings was a dead horse, and that since 1789 the real enemy of individual freedom was what we have called totalitarian democracy"25, or in the words of Constant himself, pointing to the real source of this modern totalitarianism: "... The grossest sophisms of the most ferocious apostles of terror... the most revolting inferences were nothing but perfectly justified conclusions from Rousseau" 26. In his "De la force du Gouvernement actuel et de la nécessité de s'y rallier" (1796) Constant had emphasized that principles were more important than either men and institutions and that "an arbitrary system is the supreme enemy of Liberty, the corrupting vice of every institution, the germ of death which must be extirpated and destroyed" ${ }^{27}$, and further, "in science the arbitrary method means the destruction of all science; in morals, the destruction of all morals; in politics, the destruction of all institutions..."28.

Later, in his "De l'Esprit de conquête et de l'usurpation dans leurs rapports avec la civilisation européenne" (Paris, 1814), he attacked the Napoleonic despotism and continued his passionate defense of liberty. Constant saw little difference between the totalitarianism of the democratic fanatics of virtue à la Robespierre and the despotism of Bonaparte's Empire.

Although an opportunist in many ways, since he was willing to cooperate with the Bonapartists if they accepted his liberal philosophy, Constant nonetheless always adhered to one basic principle: liberalism and constitutional monarchy. „For forty years... I have fought for the same principle: liberty in all things, in religion, in philosophy, in literature, in industry, in politics. By liberty, I mean the triumph of the individual, as much over a government which seeks to rule by despotic methods as over the masses who seek to render the minority a slave of the majority. Despotism has no rights at all29." However, Constant tempered this individualism with his conservative leanings so that his ideal - constitutional monarchy would include essentially the same package as that of the Doctrinaires: the responsibility of ministers, the neutrality of the Crown, a hereditary peerage, an unpaid representative legislature, trial by jury, religious tolerance, and freedom of the press. They were all part of his constitutional monarchy which could be sufficiently flexible to harmonize both the extremes of the old monarchical principle and the new idea of full individual liberty ${ }^{30}$.

Benjamin Constant influenced both liberals and conservatives in Europe, but especially those countries where royalty had either lost out or where the crowns were shaky; even as late as 1905 was his name mentioned in Russia ${ }^{31}$. The ideas of Constant came to Hispanic America as part of the influence of Romantic Liberalism, and basically with the Doctrinaire Liberal movement. The ecclectic philosophy of Cousin was the first sign of the Romantic invasion during the final

25 J. L. Talmon, Political Messianism. The Romantic Phase (London, 1960), p. 318.

26 Ibid., quoted from Benjamin Constant, Oeuvres, politiques, p. 15

27 Harold Nicolson, Benjamin Constant (London, 1949), p. 130.

28 Ibid.

29 Ibid., p. 253

30 Ibid., p. 216.

31 Gall, p. 174 . 
stages of the Hispanic American emancipation, although the pre-Romantic spirit of Rousseau had already arrived earlier. Ecclecticism was received in Hispanic America with great interest, perhaps with even greater enthusiasm than in Europe itself since it was believed that it could give the answers which the Enlightenment had failed to provide.

Thus, rationalism and universalism of the Age of Reason were replaced with the new Liberal creed of the Romantic Age and Ecclecticsm, as Ramón Insúa Rodríguez stated, imposed itself triumphantly in Hispanic America without, however, taking firm roots ${ }^{32}$. Most of the intellectuals in Hispanic America who embraced the Ecclectic movement were not philosophers but men of letters and politicians. In any case the influence of the 'Rechtsstaat', of modern constitutional government in general and of the Doctrinaire movement and the Liberalism of Constant in particular, was no doubt extraordinary. The Liberal ideas of the Romantic Age, just as others before and thereafter, were introduced into Hispanic America not in a pure way but in a rather distorted fashion. Thus, there was scarcely a copy which came close to the French original or to any 'Rechtsstaat', of Western European roots. What was copied was rather the form not the substance. In a different environment with such a varied historical and cultural background constitutionalism was to remain highly artificial, and to the superficiality of constitutionalism came also another factor: the progressive falsification of the character of representation in which constitutionalism simply became an instrument of the oligarchy to maintain itself in power. The Doctrinaire movement as well as Constant's Liberalism appealed to Hispanic America for a number of reasons. They were part of the latest political movement coming from Europe, the dernier cri in political theory, and they fitted the elitist and conservative aristocracy, although Hispanic American idealism required that these ideas be incorporated into the constitutionalist Zeitgeist.

\section{River Plate}

As in other parts of Hispanic America Liberalism had come to the fore in the 1820 s, at the end of the struggle for independence, and especially with the establishment of independent states. In Argentina this was the case of Bernardino Rivadavia (1819-1827). Although Rivadavia was a representative of the Enlightenment and held a philosophy of life which was shaped after that of King Charles III, was influenced by the Utilitarianism of Bentham and by the idéologues - as a matter of fact Rivadavia was actually Bentham on the River Plate - certain Romantic currents like that of Constant also influenced him highly. Thus it was no surprise - since Constant would agree with many liberal ideas of Bentham that Constant's „De la Religion considérée dans sa source, ses formes et ses développements" (1824) and the "Cours de Politique Constitutionelle" could be found in Rivadavias' library. Vicente Fidel López said in this connection, and regarding the Buenos Aires version of the Parisian salons in which Rivadavia played a leading role: “... Sometimes the participants, ladies and gentlemen, formed a group around that avid reader don Tomás de Luca, to hear what the latest

32 Ramón Insúa Rodríguez, Historia de la filosofía en Hispanoamérica (Guayaquil, 1945), p. 292. 
pamphlet of M. de Pradt said in favor of (Spanish) America against Spain and the Holy Alliance; on other (occasions) it was Benjamin Constant or Bentham in favor of liberty and the representative system." 33

Constant was a great intellectual influence which joined that of Bentham and the idéologues in Rivadavia's progressive policies regarding individualism and the representative government in the 1820 s, though Rivadavia obviously only picked up what suited him best. Constant also influenced to some extent the first Argentine constitutions of 1819 and 1826: the bicameral system and the bill of rights were principles advanced and popularized by Constant even if the direct source was the Constitution of the United States. Had Argentina at that time been successful in establishing a monarchy - as was the goal of every single Argentine government since the establishment of the Buenos Aires junta of 1810, and especially of Rivadavia - the impact of Constant and the Doctrinaires would have been even greater.

Rivadavia's Enlightened Despotism and his Benthamite approach had the consequence that the federalist interior provinces revolted whose regional soul the liberal and cosmopolitan Rivadavia never really understood. The result was the regime of Juan Manuel de Rosas (1829-1852).

A group of eminent Argentine thinkers who were forced into exile by Rosas, the Generación de 1837, became the standard bearers of Romantic Liberalism: Esteban Echeverría (1809-1851), Juan Bautista Alberdi (1814-1886), Nicolás Avellaneda (1836-1885), Domingo Faustino Sarmiento (1811-1888), José María Gutiérrez (1809-1878), Bartolomé Mitre (1821-1906) and Vicente Fidel López (1815-1903). It was this Romantic liberal generation which after the fall of Rosas laid the foundations of modern Argentina through the Constitution of 1853. This Romantic generation, rather homogeneous in comparison with Chile's Generación de 1842, was influenced by Herder and Vico, and by Saint Simon's and Lerroux' Utopian Socialism, Mazzini's nationalism, Lamennais' metaphysics and democracy, by Savigny's Historicism as well as by the Doctrinaires of Royer-Collard and the liberalism of Constant, and the Ecclecticism of Cousin. Thus idealism, nationalism, Historicism - Romanticism - , or said differently: Herder, Mazzini, Savigny, with Hegel through Cousin and Saint Simon were the strong impacts on Echeverría and Alberdi. Constant played a rather strong role in Alberdi's "Fragmento preliminar al estudio del derecho". In this study there was also an influence of the Doctrinaires (Guizot) and of the Liberalism of Constant and Tocqueville as expressed in regard to the continuous anarchy in Mexico which Argentina should avoid. Alberdi proposed a more realistic approach: the universalism of the eighteenth century should be ignored and Rousseau's ideology ought not to be followed blindly "as already Benjamin Constant had written." 34

It was also through Cousin, Guizot and Lerminier, that Echeverría received the impact of Savigny's Historicism, and what was Echeverría's Young Argentina (modelled after Mazzini's Young Switzerland and Young Italy) - which was supposed to become the third party after the Unitarios and the Federales - but the Hegelian synthesis as applied to the Argentine situation? As such it will find its Hegelian climax in the Constitution of 1853 after the fall of Rosas.

33 Ricardo Piccirilli, Rivadavia y su tiempo (2 vols.; Buenos Aires, 1943), i, 357-58, footnote 1, quoted from Vicente Fidel López, Historia de la República Argentina, ix, 39.

34 Manuel Fraga Iribarne, "Prólogo", in Faustino J. Legón and Samuel W. Medrano, Las constituciones de la República Argentina (Madrid, 1953), p. xlv, footnote 82. 
Domingo Faustino Sarmiento was particularly caught in the web of the Romantic European influence. In his Facundo (chapter VII: Sociabilidad, 1825) he echoed the general Romantic trends which rejected the universalist and rationalistic theories of the Enlightenment when he said: “... Today the studies on the constitutions, races, beliefs, finally history, have vulgarized certain practical knowledge which encourage us against the brilliancy of the a priori-conceived theories; but before 1820 nothing of this had become known in the European world. With the paradox elements of the Contrat social France revolted; Buenos Aires did the same; Montesquieu distinguished three branches of government, and exactly three did we have; Benjamin Constant and Bentham annulled the Executive, likewise was it established there; Say and Smith preached free trade, and free commerce was then repeated there. Buenos Aires confessed and believed everything that the savant world of Europe believed and confessed. Only after the Revolution of 1830 in France and after its incomplete results do the social sciences take a new direction and do the illusions begin to vanish. From then on European books begin to arrive which show us that Voltaire was not so right after all, that Rousseau was a sophist, that Mably and Raynal (were) both anarchists, that there are no three powers, not even a social contract, etc. From then on we know something about races, tendencies, national customs, historical antecedents. Tocqueville reveals for the first time the secret of the United States; Sismondi discovers us the vacuum of the constitutions; Thierry, Michelet and Guizot, the spirit of History; the Revolution of 1830 all the deception of Benjamin Constant's constitutionalism; the Spanish revolution everything which is incomplete and backward in our race." 35 Notwithstanding the misinterpretation of Constant by Sarmiento, the latter statement showed the impact of the European Romantic currents of thought on the Argentine Generación de 1837 and represented an impressive document for the study of ideas in contemporary Argentina. The Constitution of 1853, the Hegelian synthesis between the liberalism of the Unitarios, the May Revolution, and the conservative though also democratic federalism of the interior, was the result of these varied influences: from Utopian Socialism, nationalism, Historicism, German Idealism, to Ecclecticism and the ideas of the Doctrinaire Liberal movement.

Argentina's neighbor U r u g u y witnessed a similar evolution. From 1830 to 1875 - the "Period of National Anarchy” - both the Utilitarianism of Bentham and the Idéologie of Destutt de Tracy were followed by Cousin's Ecclecticism and the Utopian Socialism of Saint Simon. Cousin's Ecclecticism was taught by Luis José de la Peña, the founder of the Liceo Nacional. With the fall of Rosas (1852), Peña returned to Buenos Aires and was succeeded by Plácido Ellauri who until 1885 held the chair of philosophy at the university (except for the years 1877 until 1883 when President Latorre suppressed it).

The philosophy of Cousin dominated the educated circles of Montevideo between 1849 and 1875. Just as in Argentina, the fall of Rosas led to a constitutionalist opening in Uruguay: the university, closed before the "Great War" (1843-1851), reopened in 1849 and thereupon fell under the spell of Cousin's Ecclecticism. As Antonio Ardao summarizes, the ideas prevailing in contemporary Uruguay were

35 Domingo Faustino Sarmiento, Facundo. Recuerdos de provincia (Madrid, 1950), pp. $183-84$. 
not different from those in other parts of Hispanic America, i. e. 1. Romanticism in literature. 2. "Principismo" in political theory. 3. Rationalistic Deism in religion. 4. Secularization in education ${ }^{36}$.

"Principismo" was basically the attempt to apply the political theories of the Rechtsstaat to the Uruguayan situation in which Constant's ideas also played a great role. However, these political ideas remained largely a dream since the "Period of National Anarchy" could hardly give an opportunity to the application of such constitutionalist concepts. "Principismo", the Uruguayan version of Cousin's Ecclecticism and the political ideas of Royer-Collard's Doctrinaire Liberalism faced caudillismo and lost out. The famous first Uruguayan Constitution of 1830, modelled after Rivadavia's Constitution of 1826, remained a beautiful dream. After the "Great War" Romantic Liberalism ushered into many constitutional studies, and it was particularly in the period of $1865-1875$ that this Romantic Liberalism got into power and attempted to set up a Liberal state according to the general lines of the Doctrinaire Libaral model. The period of Venancio Flores was best represented by the "civilistas" and "principistas" of 1872 , by the "brilliant chamber" of 1873 , even though the attempt to establish the Uruguayan version of the Rechtsstaat by the doctores of 1873 remained an utopia - it simply collided with the reality of contemporary Uruguay. However, the "principistas" obtained an electoral victory in 1887, and this date marked the transition from military dictatorhip (Latorre, Santos) to civilian rule (Tajes, Herrera y Obés, Batlle). It also showed how long and deep the influence of European Romantic Liberalism (both Doctrinaire Liberalism and Utopian Socialism) remained in Uruguay despite the increasing currents of Positivism.

\section{Brazil}

The European influence was particularly strong in this country since the monarchy had such close relations with the courts of Lisbon, Madrid and Vienna, and this was particularly true in the Romantic Age. Cousin's greatest disciple in Brazil was Father Francisco Mont'Alverne (1784-1858) who taught at the College of St. John in Rio de Janeiro. For Mont'Alverne Ecclecticism seemed to provide the best solution to all philosophical and political problems since it attempted to conciliate the most different opinions: Hegel, Kant, the Scottish School, Herder, Savigny, and the Enlightenment. It is also a fact that during the debates on the Brazilian Constitution in the Apostolado, he defended the political ideas of Constant which then appeared in the Imperial Charter of 1824. Another follower of Cousin was Mont' Alverne's disciple Domingo Gonçalves de Magalhāes. In France, where he studied for some time, Goncalves de Magalhāes also received the influence of Jouffroy, the rationalistic ecclectic and the voice of Herder in that country. Finally, also Tobias Barreto, the famous forerunner of German philosophy in Brazil, in his youth fell under the spell of Cousin's Eclecticism; it was in the period between 1861 and 1865 that he felt attracted to the ecclectic spiritualism of Cousin and to the philosophies of Maine de Biram and Royer-Collard.

36 Arturo Ardao, Espiritualismo y positivismo en el Uruguay (Mexico, 1950), p. 50. 
Ecclecticism appeared to the educated Brazilians as the philosophy which could best explain the political situation in Brazil after it had become independent and set up a monarchical government. While the Brazilian idéologues supported republicanism and its numerous plots $(1817,1824,1835)$, the followers of Ecclecticism preferred the Imperial government of Dom Pedro I with the famous Constitution of 1824. Ecclecticism provided the intellectual foundation for the support of monarchy and served the purpose of securing stability and strength for the Empire. Ecclecticism thus became the instrument and the weapon of monarchy and offered its supporters a practical political basis and a platform which was still going strong at the end of the Imperial period. With the acceptance of Ecclecticism in the field of philosophy it was obvious that Doctrinaire Liberalism would also receive a great welcome by both conservative and liberal supporters of the regime. The great monument of Doctrinaire Liberal thought in Brazil was the Imperial Constitution of 1824 . First elaborated by more radical elements, then entrusted by the young emperor to his council of state, this charter followed especially the French model of 1814, although the Constitution of Cádiz of 1812 and that of Portugal of 1822 were also present. The Imperial Constitution was a constitution octroyée like that of France of 1814 in the sense that Dom Pedro I granted it to his people in a unilateral act - it was not based on a social compact between monarch and people and forced by the people on their ruler. In true Ecclectic style, the Constitution read: "By the grace of God and the unanimous acclamation of the peoples, Constitutional Emperor and Perpetual Defender of Brazil."

The similarity of the Imperial Charter with that of France was striking and went even further: the Constituent Assembly declared the basis on which the constitutional empire was to be established as "legitimate", and the Diario do Governo exhorted the emperor before the proclamation of the constitution "to grant Brazil a Charter as Louis XVIII had done in France." 37

The great Brazilian Doctrinaire Liberal was José Antonio Pimenta Bueno, later Marquis de Sāo Vicente, who stated that "In a constitutional monarchy it is not enough to divide a general assembly into two chambers; it is necessary to give the legislative power a further branch: to link it to the Crown is a necessary condition and even inseperable from that type of government; the monarch would lose his character from the moment he would cease having this function, from the moment he would not be an integral part of that power."33

Through the sanction of the laws or their denial, the Emperor became a part of the legislative power. The above thought of Pimenta Bueno reflected ideas from Royer-Collard and his movement in the sense that the legislative branch was held collectively by the king and the two chambers, and actually went back to Hispanic medieval political ideas as well.

Constant's importance can be clearly seen in the respect for individual rights and the protection of the constitution, although the question of individual rights was also rooted in the idéologues. The proctection of the charter was carried out by parliament in relation to actions of the executive power. Suffrage and eligibility to

37 Octacilio Alecrim, Idéias e Instituções no Império (Rio de Janairo, 1953), p. 68, footnote. The drafters of the constitution were inspired by a number of French authors. The Diario do Governo of March 27, 1824, gives an impressive list of specialized books on the subject of "the representative constitutional monarchical system", as listed by the Imperial librarian Plancher, such as the works by Ferrières, Rolland, Riouffe, Massabiau - the latter violently anti-republican (Ibid., pp. 39/40).

38 Ibid., p. 125, quoting José Antonio Pimenta Bueno, Anályse da Constituição do Império (Rio de Janeiro, 1857). 
public office were limited to a certain income - a definite echo of the Restoration and the Doctrinaire movement. The Constitution adopted the bicameral system following the French Charter of 1814 and the Anglo-Saxon models; it thus disregarded the revolutionary French model of 1791 as well as those inspired by the Spanish doceañistas. For this solution several sources seem to have been responsible: Bentham's preference for the Constitution of the United States, Constant's advocacy of the British unwritten constitution and the mentioned French Charter of 1814.

The unique constitutional innovation was the fourth power, "O Poder Moderador". It is interesting that the draft Constitution did not have this element. It was part of the executive power for which the monarch did not need the sanction of his ministers. The Emperor could apply it in the following cases: suspension of magistrates, and ad interim, suspension of the resolutions of the provincial assemblies; granting of amnesty and dissolution of the Chamber of Deputies. Moreover, the monarch as moderating power was supposed to consult the Council of State in grave matters of an administrative character, declaration of war, making of peace, negotiations with foreign powers, whenever it was a faculty of the moderating power. Just as the monarch was helped in his executive duties by the responsibility of the ministers, the Emperor in return, when acting as moderating power, was protected by the Constitution, i. e. by the responsibility of the members of the Council of State. The Poder Moderador, the Brazilian pouvoir neutre, was the key to the entire constitutional system - it was the most important political means put at the disposal of the Emperor, particularly since parliamentarism introduced itself slowly. The Poder Moderador was an element of balance and harmony among the other branches of government and Dom Pedro II made an excellent use of it thus giving the country the stability it needed for a peaceful evolution. It was Dom Pedro II who consolidated the organization of the country after a period of uncertainty during the reign of Dom Pedro I and the Regency. With the rule of Dom Pedro II the Poder Moderador became the so-called "dictatorship of honesty". Although it transformed itself into the personal power of the emperor, the latter always used it with high public spirit. It did not follow the motto of "The king rules but does not govern" as in Louis Philippe's France though at the same time Brazil escaped the instability and the frequent crises which characterized most pseudoparliamentary regimes of Spanish America. The Empire of Brazil thus echoed as no other country in Hispanic America both the Restoration and the July Monarchy as it had earlier done when it had been a quasi extension of the Holy Alliance on American soil.

The influence of the Doctrinaire movement and of Constant showed itself further in the establishment of chairs of constitutional law: in 1827 the faculties of both Olinda and Sāo Paulo set up special chairs for an analytical study of the Imperial Charter in which the mixed, constitutional and representative system of government could be taught. It also manifested itself in the truly remarkable amount of Brazilian studies on the subject of the Rechtsstaat, thus following again the French and other European examples (Guizot, Rossi, Saint Girous, Gneist, Sacedo, Trono, Morea, Palma) $)^{39}$. The most important Brazilian book on the subject remained

\footnotetext{
39 Alecrim, pp. $80-83$.
} 
Pimenta Bueno's “Direito Publico Brasileiro e Analyse da Constitução do Imperio" ${ }^{40}$, the Brazilian version of the Doctrinaire Liberals, a work which never lost its popularity. Finally, it should be mentioned that the Spanish edition of Constant's work on constitutional law - the "Curso de Política Constitucional", translated by Marcial Antonio López (Madrid, 1820) - had a wide circulation in Brazil and was very much used for constitutional discussions.

\section{The Bolivarian Area}

Constant had had an early impact in the region where Simón Bolívar ruled supreme. Alexander von Humboldt had influenced Antonio Nariño for a third solution of the Greater Colombian Constitution of Rosario de Cúcuta (1821): While Bolívar had wanted a centralized solution, and a federation meant that Colombia, Venezuela and Quito would each retain their autonomy, this third option meant six instead of three provinces ${ }^{41}$. Humboldt had outlined the borders and Constant had suggested the constitutional requirements, especially the protection of individual rights and the separation of powers.

Constant's influence, already manifested in Bolívar's advocacy of British models in Angostura (1819) and Rosario de Cúcuta (1821), came specifically to the fore in the Bolivarian or Bolivian Constitution of 1826 which included four powers: executive, legislative, judicial, and electoral. Constant had also talked of the municipal or provincial authority as a barrier to despotism, and Bolívar changed the fourth power, the pouvoir neutre, to the electoral power ${ }^{42}$. As such it became known in both the Bolivian and Peruvian constitutions of 1826, also adopted by Quito, Cartagena de Indias and Panama, although the meaning was distorted to fit the authoritarian designs of the Libertador.

In accordance with articles 19 and 20 of the Bolivian Constitution, the electoral power was formed by ten citizens: each group of ten citizens appointed an elector to represent them in the electoral body of the province. This electoral system was restricted by the requirements of citizenship (residence in the national territory, knowledge of reading and writing, and employment). The electoral bodies thus constituted worked for four years and had the following rights: citizen selection and presentation of three candidates for membership in the chambers, and for the position of prefects, governors, corregidores, mayors, judges of the peace, court judges, priests and vicars. Although the electoral power was derived from the Napoleonic constitutions of the years VIII and X, and also from the Spanish Constitution of 1812 and the Peruvian of 1823, the entire concept of having four branches of government came from Constant with whom Bolívar was well acquainted - several books of Constant could be found in Bolívar's library, such as the "Curso de Política Constitucional", and "Les Cents Jours"43. Furthermore, Bolívar revived his concept of a moral power, a kind of lay Inquisition, in the censors, who together with the tribunes and senators formed the legislative branch - this moral power also echoed the Doctrinaires and

\footnotetext{
40 (Rio de Janeiro, 1857).

41 Víctor Andrés Belaúnde, Bolívar y el pensamiento político de la Revolución hispanoamericana (Span. ed.; Madrid, 1959), p. 208.

42 Ibid., p. 248.

43 Ibid., p. 142.
} 
Constant. It is also fascinating to note that Bolívar's Napoleonic dictatorship the lifelong presidency - resulted in a fierce dispute between the Abbé de Pradt, who defended the Libertador, and Constant, who obviously did not approve, although he could not understand the different environment and the reality of Spanish America ${ }^{44}$.

Constant's concept of the fourth power witnessed an interesting revival in Colombia's Constitution of 1886, the political foundation of the conservative regime of Rafael Núñez under whom the conservatives returned to power in 1880 and kept it until 1930. Núñez was an intellectual who attempted to give his country political stability and economic development - reelected in 1884, he remained in power until his death ten years later. The conservative Constitution of 1886 established a strong state with protection of Church and religion although it allowed ample municipal freedom in the various departments into which the country was divided. It followed Bolívar' Constitution of 1826 in regard to the separation of powers and incorporated, though differently, four branches of government: executive, legislative, judicial, and electoral. The concept of the fourth power was concentrated in the electoral authority, although it could hardly be called a pure replica of the pouvoir neutre. Still, the Constitution of 1886 was viewed, at least by the conservatives, as a model for the conciliation of political stability and freedom and for the harmony of order and progress.

The man behind the constitution was Miguel Antonio Caro, perhaps the best representative of Colombia's Traditionalism. The constitution demonstrated several fascinating facts: one, that the influence of Constant was still an important element as late as the $1880 \mathrm{~s}$, and second, that despite the fact that it was a conservative document, the Constitution of 1886 followed in many respects the old Doctrinaire Liberal school of thought - which was nothing new, since this had also been true of earlier examples.

\section{Chile}

Another good example of Doctrinaire influence was Chile. The country had suffered quite some upheavals since it had set up a revolutionary junta in 1810, including a return to Spanish rule from 1814 to 1817 and a series of liberal dictatorships. Liberal mismanagement of public affairs finally resulted in a conservative victory: Lircay, April 17, 1830, which sealed the fate of the discredited pipiolos and initiated the regime of the authoritarian Diego Portales, Chile's greatest statesman in the nineteenth century. His rule made Chile the only country in Spanish America with a representative government which came quite close to the European ideal of the Rechtsstaat and which successfully set up a regime which combined political stability with a great amount of intellectual freedom. The foundation which Portales built was to endure almost until the end of the century: the victory of the parliamentary forces at Placilla (1891) interrupted this outstanding achievement.

The conservative regimes which began in 1830 with Portales were particularly outstanding under the first presidents Joaquín Prieto (1831-1841), Manuel Bulnes

44 Ibid., pp. 387-88. 
(1841-1851), and Manuel Montt (1851-1861), and found their constitutional basis in the famous Constitution of 1833. Drafted by Mariano Egaña with the aid of Manuel José Gandarillas and Andrés Bello it was the Chilean replica of the Restoration and the July Monarchy. The regime - like those in Europe was authoritarian: "... the government constituted a despotism not like those which other South American peoples had seen, but the expression of the social structure and the culture of the epoch. The Congresses were not formed of servile instruments of authority, but of the most distinguished men of the country, and the gratitude of the parliamentary functions gave rise as in old Rome to a kind of race of honors which carried the servants of the people first to the Cabildo, then to the Chamber of Deputies, to end up a devoted public life with a seat in the Senate. Within the political framework which the turbulent Spanish America of a century ago offered, Chile constituted an exception, and that atmosphere of social harmony upon which Spanish tradition was so deeply imprinted, which resulted from the code of 1833 and which the government sustained with vigorous hand, was the one which Sarmiento pointed out in an unforgetable writing." 45

It has been said that Portales represented a typical Spanish American dictator, a caudillo. However, a much more objective and less emotional approach was that of Jay Kinsbruner for whom rightly the constitution and the entire system of government was more the Chilean version of the Doctrinaire Liberal idea, the Rechtsstaat ${ }^{46}$. Symbolic for the constitution and the political regime was also the Chilean Generación de 1842, and expecially Andrés Bello, who had helped in the drafting of this famous constitutional document. Venezuelan by birth, Bello had lived in London between 1810 and 1829 and had been invited to come to Chile by Minister Portales, like so many others (the French Claude Gay, the Spaniard Andrés Antonio Gorbea, the Irish William Blest). In England Bello had developed any admiration for tolerance and for respect of law in general and for British principles of government in particular. It was also here that he fell under the spell of the Scottish school of philosophy with its emphasis on common sense. Once in Chile Bello contributed to a great extent to the prestige which that country held in the nineteenth century. For 25 years he worked in the field of educational reform whose apex was no doubt the establishment in 1842 of the University of Chile, the successor to the College of San Felipe. Bello became the first rector. Bello was always the man of the juste milieu in the classical Greek sense - he would accept new and foreign ideas as long as they did not contradict Hispanic tradition and Catholic faith. This was his characteristic element and was noticeable in all of Bello's endeavors in education, in law, in philosophy, in politics. This typical approach of his - moderate, measured, conservative, but at the same time moving ahead - was shown in the cultural field when he campaigned for better primary education, for improvement in the teaching of the arts and sciences, and for suppression of the censorship of books. In the field of law, Bello was the author of the Chilean civil code, based on Roman law and old Spanish legislation, which later served as a model in Colombia,

45 Ricardo Donoso, Las ideas políticas en Chile (Mexico, 1946), pp. 112-13.

46 Jay Kinsbruner, Diego Portales: Interpretative Essays on the Man and Times (The Hague, 1967). With reference to Andrés Bello, cf. Rafael Caldera, Andrés Bello. Philosopher, Poet, Philologist, Educator, Legislator Statesman (London, 1977). 
Ecuador, Nicaragua and Uruguay, and influenced the codes of Argentina, Brazil and Venezuela. In philosophy he was indebted to the mentioned Scottish School, expecially to Thomas Reid, the founder, and to Hamilton, much influenced by Kant. It was also in philosophy that Bello received the impact of Cousin's Ecclecticism which reflected itself in his general attitude of attempting to reach a via media, a synthesis, in all aspects of life.

It is especially in the political field that Bello showed himself to be a real ecclectic thinker and no doubt Portales found in him the right adviser for his concept of government: a strong regime based on the former monarchical traditions but within a republican framework and coupled to an evolutionary concept of progress. He was himself a constitutional monarchist and far from being caught in the web of the utopian and dangerous totalitarianism of Rousseau and the French Revolution Bello understood very early as few did that Spain and the Spanish heritage could not be eliminated and that it was a factor that was going to stay; far from blaming Spain for so many shortcomings, as so many did in those days (and still do), the old country gave Chile remarkable characteristics for which both country and people could be proud of. He was thus opposed to the tavola rasa concept of many of his Chilean friends, mostly pipiolos, who advocated a rather naive course in trying to deny the past and to reject the Spanish heritage. Instead he advocated a government based on the realities of the country which would gradually evolve into a modern state, a synthesis of tradition and progress.

The Constitution of 1833 showed this philosophy and was fundamentally a replica of the Doctrinaire Liberal movement. It manifested the influence of Spanish Liberalism and joined to it the traditional and conservative thought of Spain, England and France. The two-chamber system followed the Anglo-Saxon model and suffrage was restricted. The Senate acted as a fourth power - Constant's pouvoir neutre - in the sense that it took the role of a great moderating body. While the executive received ample powers, including extraordinary powers from Congress in case of emergencies, the constitution also acknowledged individual rights in the sense Constant would have approved.

This elected monarchy within a republican form left the president with the effective management of public affairs, a policy which his Minister Portales carried out with great statesmanship; it allowed only the Catholic faith, maintained the mayorazgos (entailed estates), and generally symbolized the vision and the statesmanship of an aristocracy which had witnessed the evil of the revolutionary creed to society and the state and which was determined to lead Chile toward a better future through the adoption of a sound political organization. The Constitution of 1833, the application of Bello's own ecclecticism, and an echo of the Doctrinaire Liberal movement and of Constant's liberalism mixed with Traditional thought, was the effective instrument to accomplish this goal.

\section{Mexico}

With the end of Iturbide's first Mexican Empire (1821-1823) the country entered a period of great political turbulence which was to last until the regime of Porfirio Díaz (1876-1911). As in other parts of Hispanic America Europe's various intellectual movements also echoed in Mexico: the Spanish period prior to 
independence represented the Mexican version of Enlightened Despotism; the revolt against the first Mexican Empire was influenced by the same currents as in the Peninsula - Enlightened Liberalism; the Liberal interlude of 1832-1835 - the first Reforma with Valentín Gómez Farías and José María Luis Mora - represented the influence of the idéologues while the conservative periods of 18291832 and $1836-1853$ projected in various degrees the impact of European Traditionalism and Doctrinaire Liberalism.

The loss of Texas brought the conservatives back into power with Lucas Alamán as the great leader, and the early symbol of this conservative period was the new Constitution of 1836 which then replaced the first liberal Constitution of 1824 . The constitution which was promulgated on December 30, 1836, is known in Mexico as the Constitución de las Siete Leyes - in the name is implied that it was a kind of modern constitutional jewel similar to the famous Siete Partidas of Alfonso X, the Learned (1252-1284). This highly centralized charter followed the ideas of Alamán and other leading Mexican conservatives and had taken over many ideas of the French Restoration and July Monarchy, i. e. from the Doctrinaire movement of Royer-Collard and Guizot and from the ideology of Constant. As in other Hispanic American imitations the application of the European Rechtsstaat in Mexico was distorted in that it simply provided the foundation and framework for the conservative oligarchy. Justo Sierra stated this well when he said: "... the conservative oligarchy organized in it its power and formulated its hopes; but the majority of the deputies belonged to the moderates and let us say liberal part of that oligarchy. Under the direct influence of the Doctrinaires who governed the monarchy of Louis Philippe our republicans had faith that the political system carefully and ingeniously organized could avoid the excesses of authority and the revolutionary convulsions; sincere foes of any despotism, that from below as that from above, and most devout towards the parliamentary regime based not on universal suffrage which not without reason seemed to them unfitting to the reality in our country, but on a regime subject to income provisions, they believed they had struck a balance between authority and freedom, within political centralism and administrative decentralization, necessary in their concept to maintain a country united which was close to being deadly threatened, that when they withdrew after invoking 'Almighty God, Three and One, for whom men are destined to establish societies, and those which have been set up, are kept', considered they had done everything possible for the happiness of the country." 47

The charter contained guarantees for individual liberties in line with the ideas of Constant; it maintained the concept of the state religion even though it kept certain regalist trends derived from unilateral interpretations of the old Patronato Real de Indias. The constitution was bicameral following the Anglo Saxon pattern and the French Restoration, and suffrage was restricted as under Louis XVIII, Charles X and Louis Philippe. However, the most fascinating innovation which was introduced into Mexican constitutional thought was the concept of the fourth power which here again was different from that of Bolívar in his Constitution of 1826 and from that of the Poder Moderador in the Imperial Constitution of Brazil of 1824. In the Mexican Constitution of 1836 the pouvoir neutre was called the

47 Justo Sierra, Evolución política del pueblo mexicano (Mexico, 1950), p. 159. 
Poder Conservador, from which the Mexican conservatives actually derived the name of their party.

The Mexican constitution introduced this fourth power as a sincere means of maintaining a balance between the different branches and with the highly idealistic concept of avoiding a despotism by any of the three powers of government. The fourth power was thus supposed to regulate the system of checks and balances so that a genuine Mexican version of the Rechtsstaat could develop: the Poder Conservador was supposed to see to it that laws were complied with, that neither violations of the constitution were committed nor its powers exceeded. It was to check the executive against abuses, to nullify irregular laws and to control the courts. It had the power to declare what the national will was in extraordinary cases and to make revolutions impossible. It was thus the device to ensure a free government and to eliminate despotism, but in reality the distorted Mexican version of the fourth power resulted in establishing the very despotism it was allegedly to suppress. In other words, the Poder Conservador centering in an inner cabinet of five ministers actually became the dictatorial power which manipulated the other three branches of government at its will. The Poder Conservador was later used in 1839 to get the notorious Antonio López de Santa Ana into power the Poder Conservador declaring on March 18, 1839 that it was the will of the nation that he should take over.

The continuous struggle between liberals and conservatives, centralists and federalists, clericals and anticlericals, then led to civil strife with President Anastasio Bustamante losing the political game: he was forced to accept the liberal Constitution of 1824 but this appeasement did not help him. After the exile of Bustamante Mexico witnessed another fascinating constitutional movement: the new Constituent Assembly of 1842 in which two draft constitutions were submitted - one, following the lines of the liberal Constitution of 1824, federalism and the idéologues, and the other more moderate draft attempting again to introduce the more conservative Liberalism of Constant and of the Doctrinaires of Guizot and Royer-Collard. The new result was, however, that the Assembly was dispersed by Santa Ana. A new Junta de Notables elaborated the Bases de Organización Política de la República Mexicana which tried a via media between the two earlier drafts: it guaranteed individual rights and the separation of powers, maintained the various fueros and was in general quite conservative. This new constitutional experience which again tried to establish a Doctrinaire Liberal regime led nowhere. It was interrupted, first by the revolt of José Joaquín Herrera in 1844 with the return to the liberal Constitution of 1824, and then by the coup of Mariano Paredes (December 1845) and the Mexican war.

The short regime of Paredes is again interesting in view of the strong monarchical agitation directed by Alamán with his mouthpiece El Tiempo and considerably aided earlier by the public letter of José María Gutiérrez de Estrada, dated August 25, 1840, addressed to President Bustamante, and advocating a European monarch as a solution to Mexican political instability. The monarchical group around Alamán, Gutiérrez de Estrada, Manuel Díaz de Bonilla and Mexican Archbishop Posada y Garduño was not an isolated case, and having the support of such an influential man as Alamán meant a great deal. As a matter of fact these groups represented a Mexican version of the July Monarchy and of the Doctrinaires, aristocratic and elitist as in contemporary France. They admired Thiers and Guizot, 
Molé and Broglie, and they were enthusiastic about the philosophy of Cousin, but naturally they only accepted what they liked and what did not run counter to the Hispanic values of Mexican society. Thus, the impacts of Voltaire on Thiers and of Protestantism on Guizot were ignored, and anything which went against the teachings of the Catholic Church was rejected, and therefore, neither freedom of thought nor religious tolerance appeared.

Alamán and the conservatives again became an important factor after the war with the United States. It was during the short and turbulent rule of President Mariano Arista that the conservatives rose up and set up the Junta del Hospicio (October 20, 1850) which called on Santa Ana to return from exile. The new conservative government (1853) under Santa Ana appointed Alamán President of the Council of Ministers and Minister of Foreign Affairs. However, the death of Alamán in the year 1853 deprived the conservatives of their greatest asset and signaled the coming end of Santa Ana's last regime.

The next and last attempt to introduce the Doctrinaire Liberal ideology in Mexico was linked to the second Mexican Empire of Maximilian and Charlotte (1863-1867). Established as the result of new anarchy and the harsh anticlerical and antireligious measures of the second Reforma (1855-1867), including a new civil war (1858-1860), the second Empire certainly was very much in the spirit of Alamán. The new liberalism of Maximilian was definitely in line with the European mid-century concept of the Rechtsstaat and was actually more European than Alamán's earlier applications of Doctrinaire thought. Alamán had applied to Mexico the more historical and traditional elements than the French nineteenthcentury concepts of Ecclecticism and Doctrinaire Liberalism while Maximilian's efforts represented an attempt, futile at that, of a real conciliation of the extreme poles of politics and ideology in contemporary Mexico. With the end of Maximilian at the Cerro de las campanas on June 19, 1867, also terminates the influence which the Doctrinaire Liberals of Royer-Collard and the Liberal ideology of Constant had exercised on the Mexican conservatives and moderate liberals, and a new chapter, that of Positivism, would open in Mexico's great historical development.

The conservative Alamán, dean of the Mexican conservative party and not only a great statesman and politician but a famous historian and economist, was a foe of the French Revolution and of all that it meant politically, socially and philosophically. In contrast, he had called the regime of Louis Philippe a monument of wisdom, and in the 1830s when he had twice the opportunity to enforce his political views, he stated with regard to the July Monarchy: "The first goal of the French, Alamán wrote in the Registro Oficial, was to avoid anarchy continuing the same form of government; the second, to avoid questions of hereditary succession, always a cause of civil war; and the third, to rectify, determine and better specify the express agreement of the people and the monarch ${ }^{40}$ ". Horrified also by the continuous chaos in Mexico and across the border in Central America all his life he tried to impose on his country a conservative solution which was rooted not only in Traditionalism, but which owed very much to the political thought of the Restoration and the July Monarchy, to the Ecclecticism of Cousin, the Doctrinaires of Royer-Collard and to the Liberalism of Constant.

48 Luis Chávez Orozco, „Lucas Alamán, una faceta ${ }^{\star}$, Cuadernos Americanos (Mexico), II, X, 4 (JulyAugust 1943), 161-62. 


\section{Peru}

No country had seen a greater political anarchy in Spanish America after the end of Spanish rule than Peru. On the other hand few had witnessed the application of so many political ideologies in such a short time than this Andean country. With no revolutionary movement of its own during the period of emancipation, Peru had seen in quick succession the application of British constitutional concepts with the Protectorate of San Martín, Enlightened and doceañista Liberalism with the Constitution of 1823, and Napoleonic caesarism with the Constitution of 1826. The period of the Enlightenment came to an end with the year 1840 when Condillac and Locke, sensualism and empiricism, were replaced with Cousin and Royer-Collard. The decades from 1840 to 1860 represented the period of Romanticism in Peru, and it was then that the great debates took place between the new liberal and conservative leaders, between the brothers José and Pedro Gálvez, Benito Lazo and Francisco de Paula González Vigil, on the liberal side, and Bartolomé Herrera on the conservative side.

The conservative influence centered around the impressive Herrera (1808-1864), perhaps the greatest nineteenth-century thinker of Peru. Student of San Marcos where he received his doctorate in theology and law (1828), he became a priest and taught at the College of San Carlos. During the presidency of José Rufino Echenique (1851-1854) Herrera held the positions of minister of justice, education and foreign affairs, and his record as a public servant was extremely positive. $\mathrm{He}$ later became Peruvian Minister to the Holy Sea. Rector of the College of San Marcos, Bishop of Arequipa and conservative statesman in the best governments of nineteenth-century Peru - the periods of Marshal Ramón Castilla and Echenique - Herrera was the symbol of the Peruvian conservative tradition. Although Herrera is linked to the Traditionalist influence in his country and to the impact of Juan Donoso Cortés, in his earlier period he was much attracted to the Doctrinaire Liberal movement. As a matter of fact, it was Herrera who in the College of San Carlos had introduced Cousin, and also Krause, which philosophies then replaced the sensualism of Condillac, and Ahrens' philosophy of law took the place which earlier had been maintained by Heineccius' natural law. Herrera was not a friend of democracy which he considered totally unsuited to his beloved Peru. As a matter of fact the more he advanced in age the more he veered toward a more extreme conservative point of view. However, despite his neo-Scholasticism and Traditionalism, he accepted constitutionalism and certain features of the Doctrinaire movement, as can be seen in his draft Constitution of 1860. The anarchic situation in Peru called for a political solution which was neither a dictatorship as Bolívar's or his imitators' (Orbegoso, Salaverry, La Mar, Gamarra) nor an unruly democracy in line with the Constitution of 1823, but one which while strong would at the same time acknowledge individual rights. There is doubtless an impact of the Ecclectic movement to return to traditional values, and Herrera used this French current of thought to strengthen his own Hispanic values of traditional government. Herrera was particularly fond of Guizot and his "Histoire de la Révolution en Europe depuis la chute de l'Empire Romain jusqu'à la Révolution Française", and his criticism of Rousseau and the French Revolution was of course as much in line with Scholasticism and the Traditionalist point of view of De Maître, De Bonald and Donoso Cortés as with the Doctrinaire movement of Royer-Collard and the Liberal opinions of Constant. 
Herrera's draft Constitution of 1860 showed especially the influence of Constant: it has four branches of government - executive, legislative, judicial, and conservative. This draft contained a republican system of government, a strong executive and a bicameral representation. Suffrage was restricted and constitutional guarantees could be suspended if authorized by Congress. The president could be impeached only while in office in case of treason, plot against the form of government, dissolution of Congress, avoiding its assembly or suspending its functions. The conservative power - a new version of Constant's pouvoir neutre - was vested in the Permanent Committee of the legislative body which was to function between the bicameral meetings of Congress and was to assume a role of watchdog over the government for the guarantee of the constitution and of the laws, to solve the question of jurisdiction between the other branches, and to exercise some of these powers otherwise entrusted to the two chambers. This institution, composed of seven senators and eight deputies elected by the chambers at the end of each legislative period was revoked in 1874 and was quite unique. This fourth power was thus also different from the Mexican Poder Conservador of 1836 although the purposes and goals - the avoidance of a despotism - were similar. Herrera's other provisions in this draft were more of a traditional line and included the reestablishment of the tithe, the personal fueros and the ecclesiastical vinculaciones. His medieval concepts could be seen particularly in the rather unique proposal for a corporative senate of functional and not political character which would represent the interests of all social classes, the eternal principles of law and the solidity of the institutions; it was to be composed of capable and distinguished citizens to whom a great deal of the conservative power and some of the authority of Congress would be given when the Chamber of Deputies was in recess since the Senate was to be a permanent body ${ }^{49}$. It is again fascinating to point out how a European idea, in this case the concept of the fourth power of Constant, the pouvoir neutre, was distorted to fit the Traditionalist mind and the conservative political views of Herrera, just as it had done in a different manner in the River Plate, Brazil, Chile and Mexico, and in Bolívar's Constitution of 1826.

\section{III}

\section{Conclusion}

The Doctrinaire Liberal movement and the ideas of Benjamin Constant, especially in regard to the fourth power - the pouvoir neutre -, the system of two chambers, limited suffrage and individual rights, had a very strong appeal in Hispanic America during the nineteenth century. These ideas influenced both liberals and conservatives, although their impact was stronger on the conservative mind where these political ideas joined other streams of thought, such as Traditionalism and neo-Scholasticism. Like other currents of thought which arrived in Hispanic America the Doctrinaire Liberal concepts, and especially the idea of the pouvoir neutre, were not implemented in an unadulterated manner but instead underwent an intellectual metamorphosis: they were also humanized, personalized,

49 José Pareja Paz-Soldán, Las constituciones del Perú (Madrid, 1954), pp. 374-75. 
Hispanicized. The purest adaptation of Constant's pouvoir neutre and of the entire Doctrinaire Liberal program was Imperial Brazil with its Constitution of 1824 and the Poder Moderador. In different and rather original ways the ideas of the Doctrinaires and of Constant also influenced the constitutional concepts of Bolívar (Constitution of 1826) and the constitutional scene in Chile (Constitution of 1833), Mexico (Constitution of 1836), the River Plate (Constitution of 1853), Peru (draft Constitution of 1860), and stretched as far as the Colombian Constitution of 1886 . 
society" and provides "vertical mobility". A few of these questions are discussed in this paper which is based upon studies on West African countries, especially Ghana, Ivory Coast, Senegal, and Upper Volta.

One characteristic of these countries is their low degree of internal and intraregional integration which is combined with their partial integration in the world market. Under these conditions it can be deduced from models of regional economic growth that the result of labour migration is rather a further deepening of unequal development between immigration zones (urban agglomerations, rural export sectors) and emigration zones (mainly subsistence economies).

After labour migration has been established as a self-sustaining process during the colonial period, the changes thereby induced in the subsistence economies swell the stream of migration. After formal decolonization the increasing number of migrants meets modern urban sectors which possess only a limited absorptive capacity due to the bottlenecks of the industrialization by import substitution. Rural-urban income differences which seem responsible for the resulting urban unemployment are, however, not the primary cause of this migration process. As well, the manipulation of a single strategic variable such as urban wage rate cannot be taken as an adequate solution.

The relations of migrants with their home region extend also to the apparent "melting pot" of urban immigration areas. "Traditional" ties of this kind cross "modern" patterns of stratification. Thereby conflicts are manifested in a particularistic, e.g. "tribalist" way which hinders thorough structural changes. All together, labour migration seems to reproduce the existing structure of West African societies and even to deepen its heterogeneity. This applies to the economic as well as to the socio-political level.

\section{Benjamin Constant and the Doctrinaire Liberal Influence in Hispanic America}

\section{By O. Carlos Stoetzer}

Among the Liberal influences of the early nineteenth century, Doctrinaire Liberalism was a most important movement which shaped the Romantic mind of Hispanic America. Benjamin Constant was not strictly speaking linked to the Doctrinaires of Royer-Collard and to the ecclecticism of Cousin, but was nonetheless quite close to them. Both the Doctrinaires and the more independent mind of Constant were aristocratic: they tried to apply the Hegelian synthesis to the eternal problems of liberty and authority, and thus reflected the spirit of the industrial revolution, of the rising bourgeosie and oft the Rechtsstaat. Constant's ideal was constitutional monarchy with the fourth power, equally opposed to the enlightened despotism of the ancien régime, the totalitarian democracy of Rousseau and the French Revolution, and the democratic caesarism of Bonaparte.

Constant shaped the Liberalism of Rivadavia and the Generación de 1837 in the River Plate as well as the conservative governments of Chile (Portales and the Constitution of 1833); he influenced the Imperial Constitution of Brazil with its Poder Moderador, and he had a significant impact on Bolívar (Constitution of 1826). Furthermore, Mexico's conservative Constitution of 1835 with its 
Poder Conservador, Herrera's draft constitution of 1860 in Peru, and Núñez' Constitution of 1886 in Colombia all bear witness to his influence. However, the Doctrinaire Liberal ideas, and especially Constant's concept of the fourth power - the pouvoir neutre -, were not implemented in an unadulterated manner, except for the Brazilian case of Dom Pedro II, but instead underwent the usual intellectual metamorphosis in the Hispanic world: they were personalized, individualized, humanized - in a word, Hispanicized. 